\title{
COELIAC DISEASE IN CENTRAL AND SOUTH AMERICA: time for a concerted approach to its epidemiology
}

\author{
Affifa FARRUKH and John Francis MAYBERRY
}

\begin{abstract}
Central and South America offer an opportunity to resolve some of the current controversies that surround the epidemiology of celiac disease. Through a concerted action which brings together clinicians, researchers and patients there is an opportunity to establish robust data sets which will allow detailed analysis of environmental and genetic factors. In this review available data from the continent together with data from Spain and Italy are drawn together to give a current picture in the hope that it will stimulate further research.
\end{abstract}

HEADINGS - Celiac disease. Epidemiology. Transients and migrants. Religion and Medicine. Blood donors.

\section{INTRODUCTION}

Traditionally coeliac disease has been said to be particularly common in Ireland. As a result it has been regarded as a disease associated with Celtic communities. This belief arose largely out of work published in the British Medical Journal almost 50 years ago ${ }^{(29)}$. At that time the prevalence of coeliac disease was almost 3 cases/1000 population. Such figures appeared extra-ordinary when most diagnoses were in children and required the use of Crosby capsules or similar unpredictable technology. There were no serological tests available and the concept of a specific and sensitive diagnostic test was 40 years in the future. However, by the 21 st century comparable or greater prevalences were being reported from across the world, including Spain and Italy. The main differences between the two periods were the emergence of community screening and the easier investigation of patients with symptoms that could be linked to coeliac disease. At the beginning of the millennium Mandal and Mayberry suggested that based on a study from Brasilia which screened blood donors for potential coeliac disease the condition was likely to be significantly commoner in South America than had been thought previously ${ }^{(12,22)}$. Similar subsequent studies in Brazil have given prevalences of between 2.4 and 4.7/1000 (Table 1). However, they are based on small numbers of cases and blood donors are not truly representative of the populations from which they are drawn. However, such studies raise interesting questions as to how common coeliac disease really is in Central and South America. Are there variations between communities of different genetic backgrounds and perhaps, above all, is the region about to experience the explosion in incidence which is being described in other parts of the world?

Central and South America present a unique opportunity to investigate changes in the incidence of a number of conditions such as inflammatory bowel disease, coeliac disease and colorectal cancer. Wide area studies crossing national boundaries provide an opportunity to ensure uniform standards of diagnosis and common techniques for case detection. Such an approach was adopted in the European Union with its Concerted Actions in the late twentieth century. In addition to specific benefits in understanding of disease processes it also brought together clinicians and scientists from a wide range of backgrounds ensuring a critical mass of experienced researchers. These actions acted as a stimulus to original research and encouraged networks which have continued to the present day. If such an approach could be adopted in Central and South America its benefits for patients, clinicians and researchers are likely to be untold. 
TABLE 1. Incidence and prevalence of coeliac disease in South America and Certain European Communities

\begin{tabular}{|c|c|c|c|c|}
\hline & Years & No. of cases & Incidence cases $/ 10^{5} /$ year & Prevalence cases $/ 10^{3}$ \\
\hline \multicolumn{5}{|l|}{ UK \& Ireland } \\
\hline Cardiff ${ }^{(18,19)}$ & $1981-1995$ & 137 & 3.1 & \\
\hline East Dorset ${ }^{(11)}$ & $1993-2002$ & 159 & 8.7 & \\
\hline Leicester $^{(40)}$ & $1975-1989$ & & & \\
\hline i. Europeans & & 86 & 2.5 & \\
\hline ii. Punjabis & & 20 & 6.9 & \\
\hline \multicolumn{5}{|l|}{ Italy } \\
\hline Naples $^{(6)}$ & 2012 & 1453 & & 2.6 \\
\hline Sardinia ${ }^{(39)}$ & 2009 & 124 & & 1.2 \\
\hline Carcare $^{(25)}$ & 2006 & 10 & & 10 \\
\hline Brescia $^{(20)}$ & $1984-2000$ & 929 & 7 & \\
\hline Trieste (children) $)^{(41)}$ & $1999-2000$ & 35 & & 11 \\
\hline \multirow{2}{*}{ Brescia $^{(20)}$} & $1984-2000$ & $?$ & 4 & \\
\hline & $2000-2003$ & $?$ & 5 & \\
\hline Padua $^{(17)}$ & 1997 & $?$ & & 2.6 \\
\hline $\operatorname{Lucca}^{(26)}$ & 1996 & 2 & & 1.8 \\
\hline Ancona $^{(7)}$ & 1995 & 23 & & 4.6 \\
\hline $\operatorname{Turin}^{(3)}$ & 19751989 & 494 & 3.4 & 11.3 \\
\hline South Tirol ${ }^{(34)}$ & $1973-1982$ & & & \\
\hline German & & 45 & 10.5 & 105 \\
\hline \multicolumn{5}{|l|}{ Portugal (young people) } \\
\hline $\mathrm{Braga}^{(4)}$ & 2006 & 3 & & 7.5 \\
\hline \multicolumn{5}{|l|}{ Brazil } \\
\hline Pernambuco ${ }^{(28)}$ & 2012 & 8 & & 11.7 \\
\hline North east (African origins) ${ }^{(2)}$ & 2012 & 0 & & 0 \\
\hline Mangueirinha (Kaingang \& Guarani) ${ }^{(43)}$ & 2010 & 0 & & 0 \\
\hline \multirow{2}{*}{ Sao Paulo ${ }^{(1,30)}$} & 2012 & 14 & & 3.5 \\
\hline & 2007 & 14 & & 4.7 \\
\hline Curitiba $^{(33)}$ & 2006 & 5 & & 2.4 \\
\hline Ribeirão Preto ${ }^{(24)}$ & 2006 & 11 & & 3.7 \\
\hline Brasilia $^{(12)}$ & 2000 & 2 & & 1.5 \\
\hline \multicolumn{5}{|l|}{ Argentina } \\
\hline Buenos Aires ${ }^{(5)}$ & $1998-2006$ & 283 & & 2.2 \\
\hline La Plata ${ }^{(14)}$ & $1998-2000$ & 11 & & 6 \\
\hline \multicolumn{5}{|l|}{ Young people } \\
\hline Five areas study ${ }^{(27)}$ & $2008-2009$ & 21 & & 12.7 \\
\hline
\end{tabular}




\section{Case definition and case finding}

Central to all robust epidemiological studies is the need for a standardised definition of what constitutes the condition under investigation and so to distinguish case from noncase. When different areas are being compared it is important that comparable methods of candidate case detection are used and preferably there is a system of capture and recapture of cases, which employs different sources. This will allow a more comprehensive study with fewer cases being omitted from the analysis.

In the case of coeliac disease this is complicated by the role of antibodies in case identification, the analysis of histology and the grading of villous atrophy together with the growing controversy surrounding the concept of wheat intolerance. However, as with inflammatory bowel disease, Central and South America could answer many of the questions that now surround the changing epidemiology of coeliac disease. Through a Concerted Action which employs uniform case definitions and modes of case detection it would be possible to produce an international database through which many of these issues could be addressed. In the case of coeliac disease there would be an argument for having centres in Spain, Portugal, Italy and Ireland. The choice of these states would include many with genetic links to the populations of the continent while Ireland would act as a marker country which traditionally had a high prevalence of the condition.

Screening communities with serological tests in Central and South America has happened in Mexico ${ }^{(36)}$ and Bra$\mathrm{zil}^{(1,24,30,33)}$. However, it is only in Brazil that people with positive tests have been invited to have duodenal/jejunal biopsies to confirm the diagnosis through histology. This remains the gold standard of diagnosis and in any large scale epidemiological study histological confirmation will be essential for the data to be robust. The ideal community to be screened should be representative of society in general. However, to encourage the healthy population to participate in screening programs requires substantial funding and needs to confer specific and easily understood benefits on that community. In Argentina there is a wish to drive forward such an approach so that patients can be identified and appropriately counselled on their $\operatorname{diet}^{(8)}$. Where this is not possible other selected communities can be considered. One such group would be where there is a higher than normal prevalence of coeliac disease e.g. amongst diabetics. Here diagnosis will have a clear and readily recognised benefit for patients. In Mexico a high risk community of diabetic patients from the Mestizo community were chosen for a serological study ${ }^{(37)}$. Although a prevalence as high as 59/1000 was suggested, such data do not apply to the population in general and this is its major limitation. The significance of this limitation could be reduced through comparison of comparable patient groups across the continent. The screening of volunteers who come forward as blood donors would be more representative of the population in general. Forty four per cent of blood donors in Brazil donate for altruistic reasons and $42 \%$ in response to direct appeals ${ }^{(15,16)}$. Although such motives are reassuring it does not mean that donors are a representative cross-section of Brazilian society. However, it is likely that in many communities blood donors will have similarities and screening through blood tests may be more acceptable.

Other potential groups in whom serological screening could be considered are military recruits. Such an approach has been used in inflammatory bowel disease and can overcome some of the problems associated with case finding and the use of capture-recapture techniques ${ }^{(10)}$.

\section{Incidence versus prevalence}

Screening of communities will give prevalence data which will include asymptomatic individuals who comprise the hidden part of the iceberg which makes up the totality of the disease. In Central and South America the magnitude of this hidden component is essential to our understanding as to whether there is any significant difference in the overall prevalence when compared with data from Europe. For this reason alone, it is important that screening of communities is paralleled by incidence studies which look at symptomatic patients in the same community.

\section{Ethnic groups}

Within Spanish American society there are several interesting conjunctions with parent communities where the prevalence of celiac disease is high. These include:

Punjabi Mexicans who are predominantly to be found in Yuba City and Southern California's Imperial Valley. Migrant Punjabis have been shown to have a significantly higher incidence of the disease than the host community in Europe $^{(40)}$.

Welsh people in Patagonia, Argentina. A study using the Welsh language periodical Ninnau was carried out amongst Welsh migrants in the USA ${ }^{(35)}$. Although the Welsh speaking population is small there is a place for what might be called a "boutique" study.

German Mennonites in Argentina, Brazil, Bolivia, Belize and Paraguay of whom some believe there may be as many as 1 million.

On a wider less defined scale there were significant Italian and Irish migrations to Brazil, Argentina and Colombia. However, these communities are now more diffuse than the above groups.

Attempts have been made to assess the prevalence of coeliac disease amongst the Kaingang \& Guarani and those of African descent in Brazil and the Mestizo in Mexico ${ }^{(2,43,37)}$. However, no cases were identified in Brazil and the study in Mexico did not progress to small bowel biopsies. Although these communities may not be genetically predisposed to coeliac disease significantly larger studies are needed.

\section{Religious groups}

Although not based on ethnicity a separate approach would be to seek help from other religious groups with well defined memberships and relatively centralised records ${ }^{(23)}$. The Church of Latter Day Saints or Mormons and Adventist churches have taken part in a number of studies of cancer risk as well as of the prevalence of inflammatory bowel 
disease $^{(31,32)}$. Commitment from the churches' national leadership to epidemiology studies can ensure local co-operation and comprehensive coverage. Limitations again are similar to those seen when blood donors are studied. Adventist and Mormons are not representative of the communities from which they are drawn. However, such studies across national boundaries would allow comparisons between different states as it is likely that what draws someone to these denominations is generally similar throughout the continent. There are about 2 million Spanish speaking Mormons and 1.5 million Portuguese speakers. In the case of Adventists, the figures are approaching 1.5 million for both groups (Table 2). Such substantial communities could provide robust data on the disease's prevalence and allow direct comparisons between various regions.

TABLE 2. Estimates of Mormon and Adventist church membership in Central and South America

\begin{tabular}{lccc}
\hline Country & $\begin{array}{c}\text { Mormon } \\
\text { membership }\end{array}$ & $\begin{array}{c}\text { Adventist } \\
\text { membership }\end{array}$ & Population \\
\hline Venezuela & 161,309 & 134,302 & $30,206,307$ \\
Uruguay & 101,449 & 7,076 & $3,324,460$ \\
Peru & 543,869 & 664,016 & $30,814,175$ \\
Paraguay & 86,790 & 12,453 & $6,783,374$ \\
Ecuador & 220,247 & 52,524 & $15,783,300$ \\
Colombia & 185,891 & 221,927 & $47,681,000$ \\
Chile & 583,359 & 117,730 & $17,773,000$ \\
Brazil & $1,250,073$ & $1,330,000$ & $202,857,000$ \\
Bolivia & 188,261 & 143,029 & $10,461,053$ \\
Argentina & 421,971 & 88,956 & $42,610,981$ \\
\hline
\end{tabular}

These data are drawn from a number of sources on the internet

\section{CONCLUSION}

The creation of a network of researchers across South and Central America is a real possibility. There already exist registers of patients with coeliac disease in a number of countries together with self-help groups. Argentina has committed itself to a national drive to identify patients throughout the country. For research studies registration on computer data bases and sharing of data can be restricted by legislation related to privacy and by concerns about the availability of such data outside national boundaries. However, such difficulties can be overcome and by pooling data the results become more robust and such studies will help clarify whether the apparent increase in incidence of coeliac disease is due to a reduction in the amount of undiagnosed cases rather than a genuine change in disease frequency. It will also clarify which environmental factors are converting antibody positive people into symptomatic patients.

Patient self help groups can provide useful support through political lobbying. Such groups already exist in Brazil, Argentina, Uruguay, Chile, Mexico and Panama. The development of research networks needs to include patient groups who can help identify barriers to case detection. In addition, the facilitation of meetings and support of a research program with common protocols and clearly defined endpoints will require funding. In the case of celiac disease pharma companies have a limited role but may still provide seeding funds to, at least, initiate an international meeting of clinicians in Central and South America. From such a meeting a "concerted action" on coeliac disease can happen.

\section{Authors' contributions}

Farrukh A and Mayberry J contributed equally to the concept of the review, identification of appropriate references and production of the final text.

Farrukh A, Mayberry JF. A doença celíaca na América Central e do Sul: tempo para uma abordagem conjunta sobre sua epidemiologia. Arq Gastroenterol. 2015,52(2):129-33.

RESUMO - A América Central e do Sul oferecem uma oportunidade de resolver algumas das atuais controvérsias que cercam a epidemiologia da doença celíaca. Através de uma ação conjunta reunindo médicos, pesquisadores e pacientes, há a oportunidade para estabelecer conjuntos de dados robustos que permitirão uma análise detalhada dos fatores ambientais e genéticos envolvidos. Nesta revisão, os dados disponíveis a partir do continente, juntamente os da Espanha e da Itália, são descritos em conjunto para dar uma imagem atual, na esperança de que se estimulem novas pesquisas.

DESCRITORES - Doença celíaca. Epidemiologia. Migrantes. Religião e Medicina. Doadores de sangue. 


\section{REFERENCES}

1. Alencar ML, Ortiz-Agostinho CL, Nishitokukado L, Damião AO, Abrantes-Lemos CP, Leite AZ, et al. Prevalence of celiac disease among blood donors in São Paulo: the most populated city in Brazil. Clinics (Sao Paulo). 2012;67(9):1013-8.

2. Almeida RC, Gandolfi L, de Nazaré Klatau-Guimarães M, Ferrari I, Souse SM, Abe-Sandes k, et al. Does coeliac disease occur in Afro-derived Brazilian populations? Am J Hum Biol. 2012;24(5):710-2.

3. Ansaldi N, Dell'Olio D, Tavassoli K, Bonzano L, Guaraglia L, Norelli MT,et al. [Celiac disease in Piedmont. An epidemiological-clinical study]. Minerva Pediatrica. 1992;44(7-8):371-6. [Article in Italian]

4. Antunes H, Abreu I, Nogueiras A, Sá C, Gonçalves C, Cleto P, et al. [First determination of the prevalence of celiac disease in a Portuguese population]. Acta Med Port. 2006;19(2):115-20. [Article in Portuguese].

5. Begué C, Beratarrechea AG, Varela E, Piccioni HL, Rodoota L, Castro ME, et al. [Celiac disease: diagnosis prevalence in a community hospital]. Acta Gastroenterol Latinoam. 2010;40(4):317-22. [Article in Spanish].

6. Capuozzo M, Ottaiano A, Nava E, Cascone S, Cinque C, Iaffaioli RV, et al. Epidemiology and economic impact of celiac disease in the South vesuvian area of naples: a survey. Front Public Health. 2013;1-18. doi: 10.3389.

7. Catassi C, Rätsch IM, Fabiani E, Ricci S, Bordicchia F, Pierdomenico R, Giorgi PL. High prevalence of undiagnosed celiac disease in 5280 Italian students screened by antigliadin antibodies. Acta Paediatr. 1995;84(6):672-6.

8. Celiac Community Moves Forward in Argentina. [Accessed on 2014 Aug 15] Available from: http://www.internationaldietetics.org/Newsletter/Vol19Issue2/ Celiac-Community-Argentina.aspx

9. Corrao G, Úsai P, Galatalo G, Ansaldi N, Meini A, Pelli MA, et al. Estimating the incidence of celiac disease with capture-recapture methods within four geographic areas in Italy. J Epidemiol Community Health. 1996;50(3):299-305.

10. Farrukh A, Mayberry JF. Inflammatory Bowel Disease in Hispanic Communities: A Concerted South American Approach could identify the aetiology of Crohn's Disease and Ulcerative Colitis. Arq Gastroenterol. 2014;51(4):271-5.

11. Fowell AJ, Thomas PW, Surgenor SL, Snook JA. The epidemiology of celiac disease in East Dorset 1993 - 2002: an assessment of the 'coeliac iceberg', and preliminary evidence of case clustering. QJM. 2006;99(7):453-60.

12. Gandolfi L, Pratesi R, Cordoba JC, Tauil PL, Gasparin M, Catassi C. Prevalence of celiac disease among blood donors in Brazil. Am J Gastroenterol. 2000;95(3):579-80.

13. García Novo MD, Garfia C, Acuña Quirós MD, Asensio J, Zancada G, Barrio Gutierrez S, et al. [Prevalence of celiac disease in apparently healthy blood donors in the autonomous community of Madrid]. Rev Esp Enferm Dig. 2007;99(6):33742. [Article in Spanish].

14. Gomez JC, Selvaggio GS, Viola M, Pizarro B, la Motta G, de Barrio S, et al. Prevalence of celiac disease in Argentina: screening of an adult population in the La Plata area. Am J Gastroenterol. 2001;96(9):2700-4.

15. Gonçalez TT, Sabino EC, Chen S, Salles NA, Chamone DA, McFarland W, Murphy EL. Knowledge, attitudes and motivations among blood donors in São Paulo, Brazil. AIDS Behav. 2008;12(4 Suppl):S39-47.

16. Gonçalez TT, di Lorenzo Oliveira C, Carneiro-Proietti AB, Moreno EC, Miranda $\mathrm{C}$, Larsen N, et al. Motivation and social capital among prospective blood donors in three large blood centers in Brazil. Transfusion. 2013;53(6):1291-301.

17. Guariso G, Plebani M, Signorini R, Brigato L, Nichetti C, Celadin M, et al. [Silent celiac disease: results of a study in secondary schools of Padua]. Pediatr Med Chir. 1997; 19(2):95-8. Italian.

18. Hawkes ND, Swift GL, Smith PM, Jenkins HR. Incidence and presentation of celiac disease in South Glamorgan. Eur J Gastroenterol Hepatol. 2000;12(3):345-9.

19. Hurley JJ, Lee B, Turner JK, Beale A, Jenkins HR, Swift GL. Incidence and presentation of reported celiac disease in Cardiff and the Vale of Glamorgan: the next 10 years. Eur J Gastroenterol Hepatol. 2012;24(5):482-6.

20. Lanzini A, Villanacci V, Apillan N, Lanzarotto F, Pirali F, Arnato M, et al. Epidemiological, clinical and histopathologic characteristics of celiac disease: results of a case-finding population-based program in an Italian community. Scand J Gastroenterol. 2005;40(8):950-7.

21. Lojpez-Rodríquez MJ, Canal Macías ML, Lavado García JM, Sánchez Belda M, Robledo Andés P, Pedrera Zamorano JD. Epidemiological changes in diagnosed celiac disease in a population of Spanish children. Acta Paediatr. 2003;92(2):165-9.

22. Mandal A, Mayberry J. How common is celiac disease in South America? Am J Gastroenterol. 2000;95(3):579-580.
23. Mayberry JF. Epidemiological studies of gastrointestinal cancer in Christian sects. J Clin Gastroenterol. 1982;4(2):115-21.

24. Melo SB, Fernandes MI, Peres LC, Troncon LE, Galvão LC. Prevalence and demographic characteristics of celiac disease among blood donors in Ribeirão Preto, State of São Paulo, Brazil. Dig Dis Sci. 2006;51(5):1020-5.

25. Menardo G, Brizzolara R, Bonassi S, Marchetti A, Dante GL, Pistone C, et al Population screening for celiac disease in a low prevalence area in Italy. Scand J Gastroenterol. 2006;41(12):1414-20.

26. Montesanti M, Domenici R, Matteucci L, Mei E. [Screening for celiac disease in children attending secondary school around Lucca]. Minerva Pediatr. 1996;48(11):475-83. [Article in Italian].

27. Mora M, Litwin N, Toca MC, Azcona MI, Solís Neffa R, Battison F, et al. Prevalence of celiac disease: multicentric trial among pediatric population from five urban districts in Argentina. Arch Argent Pediatr. 2012;110(6):490-5. [Article in English, Spanish].

28. Moura ACA, de Castro-Antunes MM, de Lima LAM, de Melo Nobre Maria JM, Motta EFA, da Silva GAP. Triagem sorológica para doença celíaca em adolescentes e adultos jovens, estudantes universitários. Rev Bras Saúde Mater Infant. 2012;12:121-6.

29. Mylotte M, Egan-Mitchell B, McCarthy CF, McNicholl B. Incidence of celiac disease in the West of Ireland. British Medical Journal.1973;1(5855):703-5.

30. Oliveira RP, Sdepanian VL, Barreto JA, Cortez AJ, Carvalho FO, Bordin JO, et al. High prevalence of celiac disease in Brazilian blood donor volunteers based on screening by $\mathrm{IgA}$ antitissue transglutaminase antibody. Eur J Gastroenterol Hepatol. 2007;19(1):43-9

31. Penny WJ, Penny E, Mayberry JF, Rhodes J. Mormons, smoking and ulcerative colitis. Lancet. 1983;2(8362):1315.

32. Penny WJ, Penny E, Mayberry JF, Rhodes J. Prevalence of inflammatory bowel disease amongst Mormons in Britain and Ireland. Soc Sci Med.1995;21(3):287-90.

33. Pereira MA, Ortiz-Agostinho CL, Nishitokukado I, Sato MN, Damião AO, Alencar ML, et al. Prevalence of celiac disease in an urban area of Brazil with predominantly European ancestry. World J Gastroenterol. 2006;12(40):6546-50.

34. Pittschieler K, Reissigl H, Mengarda G. Celiac disease in two different population groups of South Tirol. J Pediatr Gastroenterol Nutr. 1988;7(3):400-2.

35. Probert C, Roberts A, Shivananda S, Mayberry J. Inflammatory bowel disease amongst Welsh migrants and their descendants in the United States of America. Eur J Gastroenterol Hepatol. 1990;2:463-5.

36. Remes-Troche JM, Ramirez-Iglesias MT, Rubio-Tapia A, Alonso-Ramos A, Velasquez A, Uscanga LF. Celiac disease could be a frequent disease in Mexico: prevalence of tissue transglutaminase antibody in healthy blood donors. J Clin Gastroenterol. 2006;40(8):697-700.

37. Remes-Rroche JM, Rios-Vaca A, Ramírez-Iglesias MT, Rubio-Tapia A, Andrade-Zarate $\mathrm{V}$, Rodríguez-Vallejo $\mathrm{F}$, et al. High prevalence of celiac disease in Mexican Mestizo adults with type 1 diabetes mellitus. J Clin Gastroenterol. 2008;42(5):460-5.

38. Riestra S, Fernández E, Rodrigo L, Garcia, Ocio G. Prevalence of celiac disease in the general population of northern Spain. Strategies of serologic screening. Scand J Gastroenterol. 2000;35(4):398-402.

39. Sardu C, Cocco E, Mereu A, Massa R, Cuccu A, Giovanna Marrosu M, Contu P. Population based study of 12 autoimmune diseases in Sardinia, Italy: Prevalence and comorbidity. PLoS One. 2012;7(3):e32487.

40. Sher KS, Fraser RC, Wicks AC, Mayberry JF. High risk of celiac disease in Punjabis. Epidemiological study in South Asian and European populations of Leicestershire. Digestion. 1993;54(3):178-82.

41. Tommasini A, Not T, Kiren V, Baldas V, Santon D, Trevisiol C, et al. Mass screening for celiac disease using antihuman transglutaminase antibody assay. Arch Dis Child. 2004;89(6):512-5.

42. Trevisiol C, Not T, Berti I, Buratti E, Città A, Neri E, et al. Screening for celiac disease in healthy blood donors at two immune-transfusion centres in north-east Italy. Ital J Gastroenterol Hepatol. 1999;31(7):584-6.

43. Utiyama SR, Ribas JL, Nisihara RM, Kotze LM, de Messiasa-Reason IJ. Celiac disease in native Indians from Brazil: a clinical and epidemiological survey. N Am J Med Sci. 2010;2(3)138-42.

44. Vitoria Cormenzana JC, Sojo Aguirre A, Martin Bejarano E, Zuazo Zamalloa E, Corera Sánchez M, Escudero Jiménez F. [Incidence of celiac disease in Vizcaya] An Esp Pediatr. 1991;35(4):251-3. [Article in Spanish]. 